Spanish, French, and English nations. Art museums are of great importance in educating the emotions and in promoting a feeling of human unity. Their policy might be to bring out that power of man over matter which is opposed both to the exploitation of poverty and to the use of power over other men.

Speaking on "The Function of Natural History Museums", Dr. W. E. Swinton, of the British Nuseum (Natural History), referred to the great facilities for education in museums, but made a plea for the education of the adult as well as the child. $A$ great deal of the so-called educational work done in museums is not related to their true function and could equally well be carried out by other institutions. The great value of natural history museums is to bring the visitor back to the basis of things. Dr. Swinton made a plea for simpler series of exhibits with ferrer specimens (and preferably some that could be handled), and with clear explanatory labels.

A private meeting of the Association discussed air raid precautions in museums, and it is understood that the recent Government handbook on this subject received some criticism.

Among the other discussions held during the Conierence was one initiated by Dr. John Rothenstein, director of the Tate Gallery, entitled "Towards a Policy for Art Galleries", and a long discussion on Mr. S. F. Markham's "Report to the Carnegio Trustees on the Museums of the British Isles".
In the course of various excursions, the long barrows of Belas Knap and Notgrovo were inspected, as were the Roman Villa at Chedworth and the new Corinium Museum at Cirencester; also the Saxon Church at Deerhurst and Tewkesbury Abboy. Gloucester Cathedral and the Gloucester Museums were also visited. Garden parties were given by Viscount Bledisloe at Lydney Park and by Mr. Robert Holland-Martin at Overbury Court.

The Conference Exhibition was one of the largest ever held. As well as various trade stands, it included a collection of photographs by the Royal Institute of British Architects to illustrate contemporarymuseum architecture; examples of Cotswold crafts; an extensive display of material from the Leicester City and County Schools Loan Department of the Leicester MIuseum; two now loan cases prepared by the Victoria and Albert Museum and three by the Yorkshire Federation; and an exhibit by the Reading Iuseum of modern methods of casting.

At the annual meeting of the Association, honorary membership was conferred upon the Right Hon. the Earl of Harewood, M. E. Foundoukidis, Dr. E. E. Lowe, Mr. T. Sheppard, and Mr. William Wyndham, and the first diplomas under the Association's training and examination scheme were presented.

The next conference of the Association will be held at the Liverpool Public Museums in July 1940.

\title{
ASSOCIATION OF SHORT-CIRCUIT TESTING AUTHORITIES
}

$\mathrm{D}$ URING the last ten years, owing to the increase in the size of electrical power generating stations and of the machines they employ, together with the greatly increased voltages used for distribution, very difficult problems in switchgear technique and design have come to the front, which make it necessary to make a practical test of modern circuit. breakers of an unprecedented size. During an accidental short circuit, enormous currents may be generated, and if the circuit bo not broken by suitablo switchgear, great damago may bo done to very expensive cables and generators. After intensive research, switchgear manufacturers realized that they must provide themselves with testing facilities on a very much larger scalo than was hitherto in existence, in order that the apparatus manufactured should meet the new conditions satisfactorily, performing its functions, to the specified ratings, to tho satisfaction both of user and manufacturer alike. The design of circuit-breakers has now become a specialized science.

The manufacturers have therefore erected highpower testing stations, fully provided with the most up-to-date equipment for the testing of circuitbreakers, fuses, reactors, transformers, etc. Without these facilities, manufacturers would have found it practically impossible to comply with the demands imposed upon them by the rapidly changing conditions in the supply industry. The owners of these high-power short-circuit testing stations soon realized that their separate endeavours would be of much greater benefit to the industry if the results of their experience and research in this highly specialized field could bo pooled, and this resulted in the formation of the Association of Short-circuit Testing
Authorities (ASTA). It is a company limited by guarantee and not having a share capital. In order to comply with the Board of Trade requirements, the articles of association provide $(a)$ that the income and property of the Association shall be applied solely to the promotion of its objects as specified in a pub. lished memorandum, and $(b)$ that no addition to tho regulations contained in the articles of association can be made without the permission of the Board of Trade.

WVe have received from the head office of the ASTA, 36 Kingsway, London, W.C.2, an interesting illustrated publication giving general information on the short-circuit testing and certification of electrical apparatus. The names of eight of the largest electrical companies in England, which form this Association, are given. Prior to the formation of ASTA, individual owners of short-circuit testing plants had tested and certified the products of some manufacturers who had no testing facilities of their own. Other manufacturers held the view that there should be a national testing plant under the control of the National Physical Laboratory and a suggestion to this effect was made to the Home Office. The Department of Scientific and Industrial Research was asked to consider this suggestion, and, in reply to a questionnaire issued by the Department, the owners of shortcircuit testing stations directed attention to the following points :

(1) That there are in existence or under construction short-circuit testing plants of a greater capacity than exist in any other country in which switchgear is being manufactured.

(2) That most of the manufacturers who havo no testing plants would be satisfied if they could obtain 
testing facilities for circuit-breakers of a maximum capacity of 250 million volt-amperes with a voltago limit of 11 kilovolts.

(3) That if the existing testing stations could place the necessary facilities at the disposal of the D.S.I.R., this scemed to bo the most economical method of meeting the situation.

The Department saw the advantage from the national point of view of utilizing the existing facilities, and it has now been agreed that tho ASTA will collectively place at the disposal of the D.S.I.R. facilities equivalent to ono 'test bay' a year for testing circuit-breakers up to the agreed limits of capacity and voltage, and, further, that the D.S.I.R. will appoint a resident officer at any test plant whero testing is being carried out, with a view to certifica. tion of the results by the National Physical Labora. tory. These arrangements will enable the N.P.L. on request to undertake, supervise and certify tho results of tests of switchgear manufactured by nonmembers of ASTA. Manufacturers wishing to have short-circuit tests carried out by the Association with a view of obtaining a certificate from the N.P.L. should apply in the first instance to the director of the National Physical Laboratory, Teddington, Middlesex. The testing stations aro at Hebburn-on-Tyne, Trafford Park (Manchester), Stafford, and Witton, Birmingham. The generators aro of unusual design, capable of short-time rated outputs in excess of the normal outputs of the largest power stations, and mechanically constructed to withstand the stresses resulting from repeated short circuits. The privacy of all tests is rigidly ensured, but a reasonable number of persons nominated by a client are welcome to witness them. Members of the Association do a considerable amount of research work, not only for manufacturers, but also in the general interests of the electrical industry.

\section{'TIME-OF-DAY' ELECTRIC TARIFFS}

$\mathrm{D}^{\mathrm{v}}$ URING the last fow years, electrical engineers have given much study to the development of tariffs for electric power which will benefit both consumer and producer and lead to an increased demand for their product. Dr. Hopkinson pointed out fifty years ago that a steady load could be generated much moro cheaply than a variable load, although their total loads for a given timo were the same. This follows because with a steady load you requiro less machines in reserve than you do when thero are peaks in the load for which much reserve plant is required which is only used for a comparatively short time. The total annual costs of a supply station depend on the running costs and tho overhead costs, the former usually being only about one eighth of the latter. Hence any saving in the capital costs of the reserve plant enables appreciable savings to be divided between producer and consumer and would probably attract new consumers. One way of securing a uniform load is by means of a 'time-of-day' tariff. The rate at which the meter registers could be controlled by a ripple current superimposed on the supply current. Tho ideal case of continuous variation would bo difficult, but if the rate at which the meter registers was changed at the supply station two or threo times a day, the consumers being notified of the times of these changes, most of them would naturally be care. ful to keep down their consumption during the times when the meter was registering a high charge. This would increase the 'diversity' of the load and make it more uniform, thus lowering the station cost.

At first sight, this seems unpractical and farfetched, but as several European cities uso a 'time-ofday' tariff the discussion of one of these methods given in a paper by D. J. Bolton of the Regent Street Polytechnic, to the Institution of Electrical Engineers, on May 10, entitled "Superimposed Control Applica. tions with Special References to Tariffs and Load Levelling", is worth studying.

The following are the details of the tariff of a Paris company. Consumers are divided into groups according to the 'size' of their installation. The size is defined by the maximum power consumption and depends on the number of rooms. The charge is $2 \mathrm{kw}$. per day for a one-room apartment, $3 \mathrm{kw}$. per day for two to four rooms, $4 \mathrm{kw}$. for five to six rooms, etc. Consumers whose power demand is less or equal to this amount are supplied through a single dial meter, and are charged at the following rate. If the first 'block' of the amount is charged at $3 d$. a unit, the second block will be charged at $1 \frac{1}{2} d$. per unit, and the remainder at $0.5 \pm d$. per unit. The size of the first block is dependent on the number of rooms, and the second block size is always half the first block size. Largo consumers can have supplies on a two. part tariff consisting of a small fixed charge to cover lighting consumption and a running charge varying with the time of the day. The fixed charge depends on the number of rooms and ranges from $11 s$. to $£ 2$ a year for a one to six room flat. In addition to this fixed charge, all the energy passes through a special meter having three registrations. These are put into operation at appropriate times of the day by means of timed relays on a centralized control system.

A Paris company was started in 1924 at a special rate for off-peak consumption but was changed into the three-rate tariff system outlined above. This tariff is little used in the purely domestic field, but there is a definite and growing utilization of it in the commercial field for large-scalo cooking, oven heating and thermal storage. There would probably soon bo a growing demand for it for domestic purposes, if the cost of the special metering required were reduced. This Paris company's charges for the peak period aro $2 \cdot 5 d$. per unit. This period lasts from 3 until 6 p.m. during the winter months. For the 'day' period, which lasts from 7 until 11 a.m. and 2 until 3 p.m. in the winter months and from 2 until 6 p.m. in summer, the price is $1 \cdot 3 d$. per unit, and for the night period and all other times it is $0.53 d$. per unit.

Mr. Bolton concludes that the function of a "timeof-day' tariff in Great Britain, both in the commercial and domestic field, would be to develop new loads not yet reached. It should supplement rather than supplant existing methods of charge. 